Jpn. J. Oral Biol., $45:$ 428-436, 2003.

\title{
ORIGINAL
}

\section{Changes of the Rat Dentin Matrix Proteins Affected by Long-term Administration of Hydroxyethylidene-1,1-bisphosphonate (HEBP)}

\author{
Yoshiyuki Wada*,**, Ryuichi Fujisawa* and Yoshinori Kuboki*,*** \\ *Department of Oral Health Science, Graduate School of Dental Medicine, Hokkaido University \\ ** Wada Dental Clinic \\ ${ }^{* * *}$ Koken Bioscience Institute \\ ${ }^{*}$ Nishi 7, Kita 13, Kita-ku, Sapporo 060-8586, Japan \\ **3-6 Fujino, Minami-ku, Sapporo 061-2283, Japan \\ ***2-13-4 Ukima, Kita-ku, Tokyo 115-0051, Japan
}

(Received on March 7, 2003 ; Accepted on September 9, 2003)

Key words: $\mathrm{HEBP} /$ dentin matrix protein/phosphophoryns/mineralization

\begin{abstract}
Bisphosphonates are widely known as inhibitors of formation and resorption of mineralized tissues. However, it is uncertain how bisphosphonates affect calcium phosphate precipitation and matrix synthesis in mineralized tissues. Several histological approaches have been done to study hard tissues affected by bisphosphonates. In this study, we used a bisphosphonate for biochemical investigation to study the mechanisms of biological mineralization and considered the effects of the bisphosphonates.

Hydroxyethylidene-1, 1-bisphosphonate (HEBP) was administered to rats by subcutaneous injection of $10 \mathrm{mg} \mathrm{P} / \mathrm{kg}$ for seven weeks. The incisors of the rats were removed and the dentin matrix proteins were analyzed biochemically. The amount of matrix proteins was relatively increased in the incisors of the experimental rats, though mineralization of the incisors of the those rats was reduced compared with that of the control rats. Dentin phosphophoryns, unique phosphoproteins of dentin, were also elevated in the experimental rats. Nevertheless, the composition of other non-collagenous proteins of dentin was essentially unchanged by the treatment.

Inhibition of mineralization by bisphosphonate may not be mediated by inhibition of synthesis of noncollagenous matrix proteins, but mainly by inhibition of calcium phosphate deposition. Moreover, it is possible that the synthesis of phosphophoryns was promoted by the treatment.
\end{abstract}

抄録：ビスホスホネートは, 石灰化組織の形成や吸収を抑制することが広く知られている。しかし, 石灰化組 織においてビスホスホネートがリン酸カルシウム沈着やマトリクス合成にどのように働いているのかは明らかで はない。ビスホスホネートを投与された硬組織を調べるためにいくつかの組織学的な試みがなされてきた。今回, われわれは生物学的石灰化のメカニズムを研究するためにビスホスホネートを用い, その作用を考察した。

$10 \mathrm{mg} \mathrm{P} / \mathrm{kg}$ の Hydroxyethylidene-1, 1-bisphosphonate (HEBP) を 7 週間ラットの皮下に注射投与した。そ の後ラットの切歯を取り出し象牙質のマトリクス蛋白質を生化学的に分析した。HEBP を投与されたラット切歯 の石灰化の程度は対照群ラットに比較して減少した。しかしマトリクス蛋白質の量は実験群のラットにおいて相 対的に増加した。象牙質独特のリン蛋白であるホスホホリンも実験群のラットにおいて増加した。にもかかわら ず，象牙質のほかの非コラーゲン蛋白の組成は本質的には HEBP 投与により変化しなかった。

ビスホスホネートによる石灰化の抑制は, 非コラーゲン基質蛋白の合成の抑制によるものではなく，主にリン 酸カルシウム沈着の抑制によるものと考えられる。さらに, ビスホスホネートによりホスホホリンの合成は促進 される可能性がある。 


\section{Introduction}

Several kinds of matrix proteins are involved in the biological mineralization of bone and teeth ${ }^{1,2)}$. Type I collagen is the most abundant protein and is thought to provide sites for calcium phosphate deposition ${ }^{3)}$. On the other hand, many acidic non-collagenous proteins (NCP) play important roles in mineralization by their capability to bind calcium ions ${ }^{4}$. In dentin, phosphophoryns are the most abundant NCP, and are rich in aspartic acid and phosphoserine. They modify calcium phosphate precipitation ${ }^{5-7)}$ and crystal growth of hydroxyapatite by their specific adsorption to crystal faces $^{8-10)}$. We demonstrated that various non-collagenous proteins of hard tissue affect mineralization in vitro ${ }^{11,12)}$. Therefore, the changes of matrix protein composition caused by drug administration may influence the mineralization processes.

Bisphosphonates are well known as inhibitors of biological mineralization and are widely used for the treatment of various bone diseases such as osteoporosis, Paget's disease and tumor hypercalcemia ${ }^{13)}$. They have $\mathrm{P}-\mathrm{C}-\mathrm{P}$ bonds replacing $\mathrm{P}-\mathrm{O}-\mathrm{P}$ bonds of inorganic pyrophosphate so that they have resistance against hydrolysis by phosphatase in vivo ${ }^{14}$.

Concerning tooth formation, several histological investigations have been done previously. In cases of single HEBP injection into rats, bisphosphonates inhibited dentin formation in two ways, via inhibition of mineral deposition and inhibition of dentin matrix formation ${ }^{15}$. In the current study, it was reported that HEBP-treated incisors demonstrated ladder-like alternate rows of mineralized and non-mineralized dentin which did not interfere with crystal growth in matrix vesicles but inhibited its outgrowth after membrane rapture in the mantle dentin ${ }^{16)}$. Furthermore, by using HEBP administration, it has been suggested that several dentin matrix proteins have an influence on mineralization by their calcium-binding properties $^{17-19}$.

The effects of bisphosphonates on hard tissue have been largely ascribed to their physicochemical properties or their influence on matrix synthesis of the cells. Previous in vitro studies have shown that they inhibit calcium phosphate precipitation, the transformation of amorphous calcium phosphate into hydroxyapatite, and the growth of crystals $^{20}$. Their pharmacological functions have been mainly examined by the histological methods described above.

It is still unclear that how the bisphosphonates affect cells and the matrix synthesis. Previously it has been said that bisphosphonates may affect matrix protein synthesis ${ }^{21,22)}$. They stimulate or inhibit bone matrix formation and bone cell activity ${ }^{23}$. The synthesis of collagen and that of free or matrix-bound phosphoproteins are reduced by short-term administration of hydroxyethylidene-1, 1-bisphosphonate (HEBP) in mouse dentin ${ }^{24)}$.

However, there have so far been few biochemical investigations on the extracellular matrix affected by bisphosphonates. Therefore, in this study, we used HEBP to study the mechanisms of mineralization and attempt to clarify the action of bisphosphonates in dentin. We investigated biochemically the rat dentin matrix proteins affected by long-term administration of HEBP.

\section{Materials and Methods}

Experiment was done following the guideline of the Committee for Animal Experiments of Hokkaido University.

\section{HEBP administration}

HEBP was purchased from Tokyo Kasei. HEBP ( $10 \mathrm{mg} \mathrm{P} / \mathrm{kg}$ body weight) in $1 \mathrm{~m} l$ of physiological saline was injected subcutaneously into the neck in Wistar King rats $(150-200 \mathrm{~g})$ once a day for seven weeks (experimental group). Another group of rats were injected with only physiological saline (control group). Three rats were used for each group. One day after the last injection the animals were killed under ether anesthesia.

Maxillary and mandibular incisors and tibiae were removed and weighed. The incisors were photographed using soft X-rays (Softex). The growth of the animals was not prominent during the experimental period. 


\section{Extraction of dentin protein}

Incisors from three rats were carefully freed of soft tissues and soft enamel and then ground into powder. The powder was washed with $0.9 \% \mathrm{NaCl}$ and decalcified with $0.5 \mathrm{M}$ EDTA and $0.05 \mathrm{M}$ Tris $/ \mathrm{HCl}$, $\mathrm{pH} 7.4$, in dialysis tubes for one week. The supernatant was desalted by dialysis against distilled water and lyophilized ( $\mathrm{E}$ fraction). The complete demineralization was judged by monitoring free calcium content in the dialysate during the demineralization procedure. Furthermore, the residues decalcified with EDTA were extracted with $4 \mathrm{M}$ guanidine $/ \mathrm{HCl}$ and $0.05 \mathrm{M}$ Tris/ $\mathrm{HCl}, \mathrm{pH} 7.4$.

Extraction of the proteins was carried out in the presence of protease inhibitors: $50 \mathrm{mM} \varepsilon$-aminocaproic acid, $5 \mathrm{mM}$ benzamidine hydrochloride, and 1 $\mathrm{mM}$ benzylsulfonyl fluoride ${ }^{25,26)}$. The extract was desalted and lyophilized as described above ( $G$ fraction). The protein content was measured by the bicinchoninic acid method (BCA protein assay, Pierce). Insoluble residues were digested with cyanogen bromide $(\mathrm{CNBr})$ in $70 \%$ formic acid. The supernatant fraction was lyophilized ( $\mathrm{CB}$ peptide). The three extracts were subjected to SDS polyacrylamide gel electrophoresis $^{12)}$. Specimens $(20 \mu \mathrm{g})$ were dissolved in a sample buffer containing 2-mercaptoethanol and heated at $100^{\circ} \mathrm{C}$ for 3 minutes. The gels were stained with Coomassie Brilliant Blue R-250 (CBB) or Stains All. We always used $12.5 \%$ gels. To examine phosphophoryns left in the insoluble matrix, acidic proteins were collected from the $\mathrm{CNBr}$ digest by $\mathrm{DEAE}$-cellulose column and were analyzed by electrophoresis as described above.

\section{PA/S staining and lectin blotting}

We performed PA/S staining and lectin blotting to investigate glycoproteins. After SDS polyacrylamide gel electrophoresis, proteins were transferred to nitrocellulose membranes (Advantec, Tokyo) by a semi-dry electroblotting apparatus (Atto, Tokyo). Then the membranes were washed with distilled water and incubated with $1 \%$ periodic acid in $3 \%$ acetic acid for 15 minutes. After rinsing with distilled water, the membranes were put into Schiff's reagent (Wako Chemicals, Osaka) for 15 minutes in the dark and color was developed with $0.5 \mathrm{M}$ sodium bisulfite ${ }^{27)}$.

For lectin blotting after transfer, the nitrocellulose membranes were washed with Tris-buffered saline (TBS ; $150 \mathrm{mM} \mathrm{NaCl}$ and $50 \mathrm{mM}$ Tris/ $\mathrm{HCl}, \mathrm{pH}$ 7.5) and blocked with $2 \%$ bovine serum albumin (BSA) in TBS. The membranes were incubated with lectins $(1 \mu \mathrm{g} / \mathrm{m} l)$ dissolved in TBS containing $0.05 \%$ Tween20 (TTBS) for two hours. Wheat germ agglutinin (WGA), concanavalin A (Con A) and Ricinus communis agglutinin (RCA) conjugated with peroxidase (Honen Corporation, Tokyo) were used as the lectins. After washing with TTBS the membranes were incubated with $0.05 \%$ diaminobenzidine (DAB) and $3 \%$ $\mathrm{H}_{2} \mathrm{O}_{2}$ in $1.5 \mathrm{mM}$ phosphate buffer, $\mathrm{pH} 6.8^{4}$.

\section{Ion exchange chromatography}

A RESOURCE-Q (Pharmacia $6.4 \times 30 \mathrm{~mm}$ ) column was used for ion exchange chromatography to quantify dentin phosphophoryns. It was eluted with a $0-0.7 \mathrm{M}$ linear gradient of $\mathrm{NaCl}$ in Tris/ $\mathrm{HCl}$ buffer, $\mathrm{pH}$ 8.2. The elution was monitored with absorbance at $230 \mathrm{~nm}$. The amounts of phosphophoryns were converted from the peak heights. The peak height was calculated using bovine phosphophoryn as the standard.

\section{Results}

\section{Effect on extractability of proteins}

The body weight of the control rat was $299 \pm 38.5 \mathrm{~g}$, while that affected by HEBP was reduced to $170 \pm$ $20.3 \mathrm{~g}$. The teeth of the experimental group were quite softened, especially on the radicular side. In the $\mathrm{X}$-ray photographs, the incisors of the control group (CT) were completely radiopaque, but the radicular two-thirds of the incisors of the experimental group (HB) were radiolucent (Fig. 1).

The protein content of each fraction is indicated in Table 1. The amounts of $\mathrm{E}$ fraction and $\mathrm{G}$ fraction were increased in the experimental group (Table 1). The extractability of dentin in our investigation was low compared with that which has been previously reported. 


\section{Effect on composition of non-collagenous proteins}

$E$ fraction, $G$ fraction and $C B$ peptide of experimen-

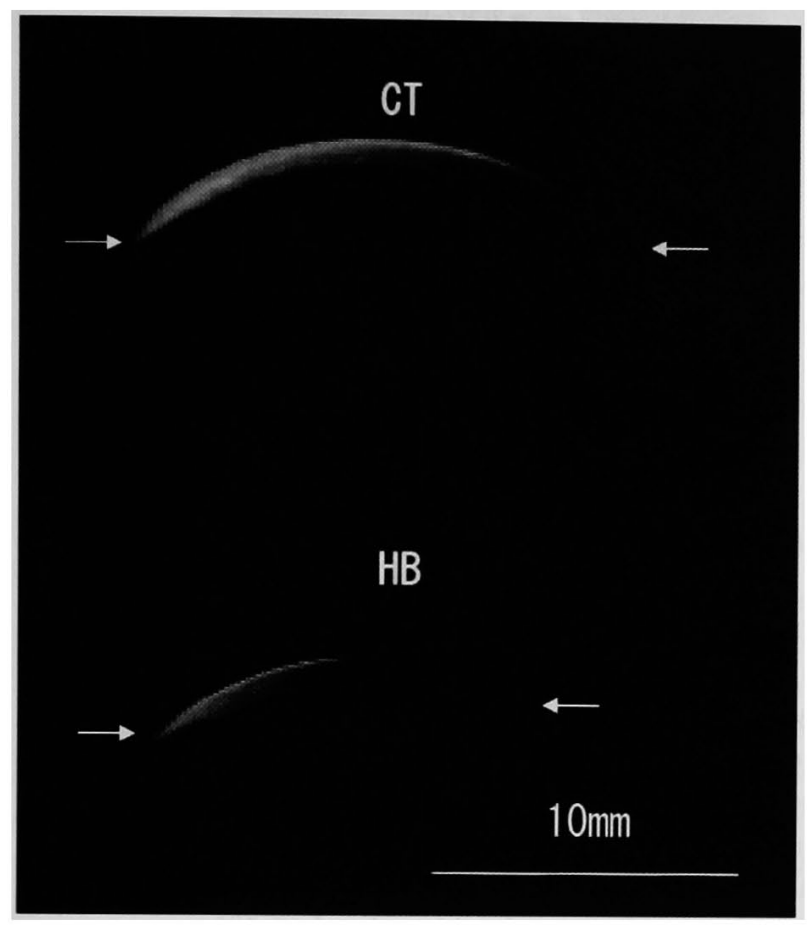

Fig. 1 X-ray photographs of mandibular incisors of rats. After seven weeks of administration of HEBP, control (CT) and experimental (HB) rat incisors were removed from alveolar bone and photographed by soft $\mathrm{X}$-ray. Control incisor dentin was radiopaque and experimental dentin was radiolucent. Arrows indicate the incisal edge and the base of the incisors. tal and control samples were analyzed by polyacrylamide gel electrophoresis. For each lane, $20 \mu \mathrm{g}$ of protein was applied. The gels were stained with $\mathrm{CBB}$ (Fig. 2 A) or Stains All (Fig. 2 B). In the E fraction lanes stained with $\mathrm{CBB}$, the same bands were observed in both the control and experimental fractions. A major $54 \mathrm{kDa}$ band could be identified as $\alpha 2 \mathrm{HS}$ glycoprotein from its apparent molecular weight. After staining with Stains All, diffuse $60 \mathrm{kDa}$ bands were observed both in experimental and control fractions. This $60 \mathrm{kDa}$ protein was dentin phosphophoryn. In the $\mathrm{G}$ fraction lanes stained with $\mathrm{CBB}$, bands of collagen and a band of $40 \mathrm{kDa}$ were observed in both the control and experimental fractions, though no band was stained with Stains All. In the cyanogen bromide peptide (CB peptide) lanes, there was no difference in the pattern stained with CBB. Several $\mathrm{CB}$ peptides of collagen were observed. No band was found with Stains All, indicating that all the phosphophoryns were extracted in the $\mathrm{E}$ fraction.

\section{PA/S staining and lectin blotting}

Only a $64 \mathrm{kDa}$ glycoprotein was stained pink by $\mathrm{PA} / \mathrm{S}$ standing in the control and experimental EDTA extract fractions (Fig. 3 A). Several bands of proteins reacted with lectins in both the experimental and control samples (Fig. 3 B). Major bands were observed at 54, 64 and $67 \mathrm{kDa}$. There was no difference of staining pattern between control and experimental fractions.

Table 1 The protein contents of each extract of the rat dentin

\begin{tabular}{lccccc}
\hline & $\begin{array}{c}\text { T.w. } \\
(\mathrm{mg})\end{array}$ & $\begin{array}{c}\text { E fraction } \\
(\mathrm{mg})\end{array}$ & $\begin{array}{c}\text { G fraction } \\
(\mathrm{mg})\end{array}$ & $\begin{array}{c}\mathrm{DPP} \\
(\mathrm{mg})\end{array}$ & $\begin{array}{c}\mathrm{DPP} / \mathrm{E} \text { fraction } \\
(\%)\end{array}$ \\
\hline $\mathrm{CT}$ & 780 & 0.92 & 0.63 & 0.63 & 68 \\
$\mathrm{HB}$ & 344 & 1.22 & 0.73 & 0.975 & 79.9 \\
\hline
\end{tabular}

The incisors extracted from control and experimental rats were removed and weighed ( $\mathrm{T}$. w.). Then they were powdered and washed with $0.9 \% \mathrm{NaCl}$. The control (CT) and experimental (HB) dentin proteins were extracted with $0.5 \mathrm{M}$ EDTA (E fraction) and $4 \mathrm{M}$ guanidine/ $\mathrm{HCl}$ ( $\mathrm{G}$ fraction)

a : Protein content was measured by bicinchoninic acid (BCA) method.

b : Quantitated by ion-exchange chromatography (see the text). 


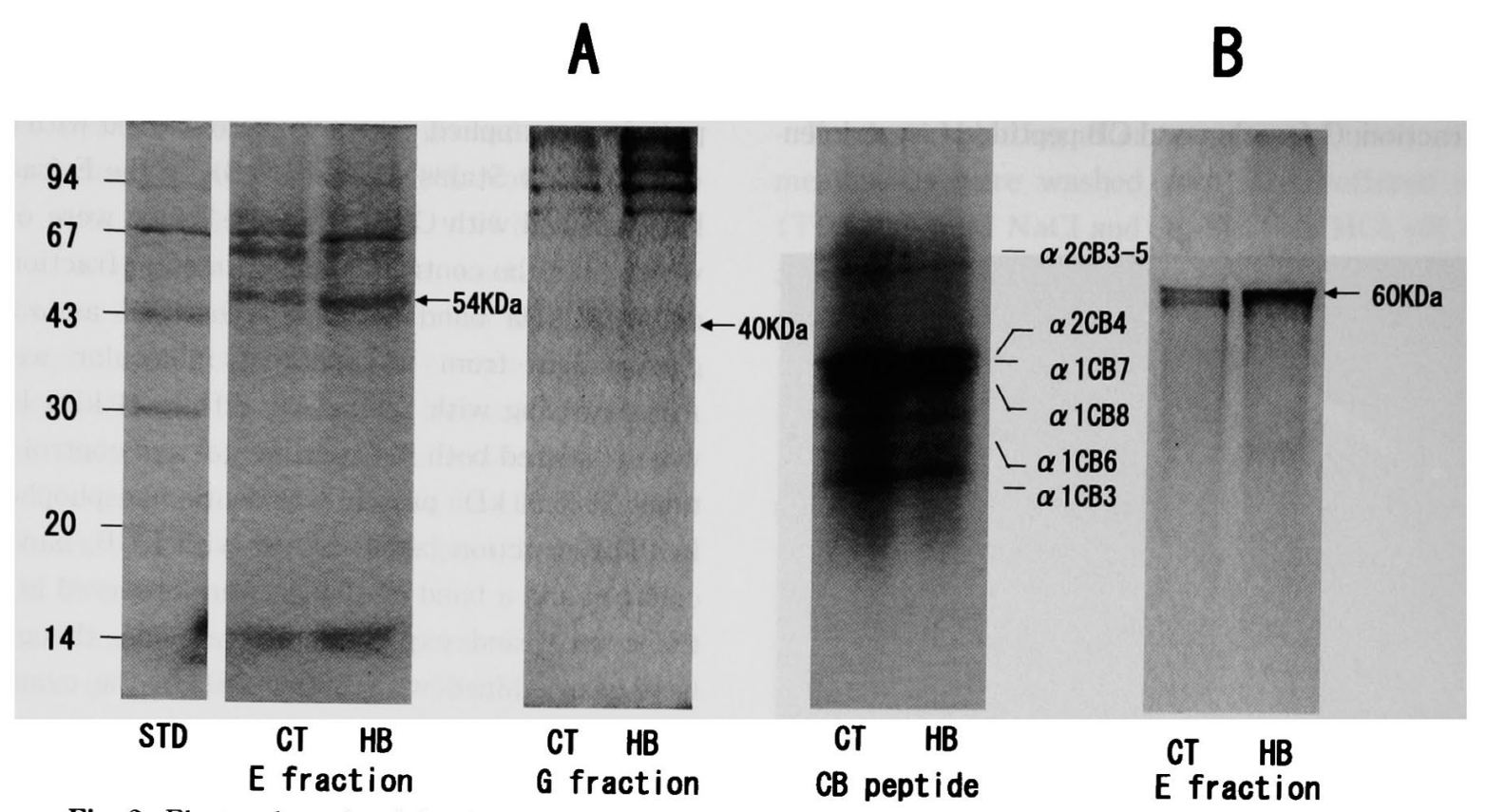

Fig. 2 Electrophoresis of dentin extracts in each extraction method. Incisors of the control (CT) and experimental (HB) rats were decalcified with 0.5 M EDTA and extracted with $4 \mathrm{M}$ guanidine/ $\mathrm{HCl}$. Insoluble matrices were digested with cyanogen bromide. The proteins of each fraction were subjected to SDS polyacrylamide gel electrophoresis, (A) and stained with Coomassie Brilliant Blue R-250 (CBB). Twenty $\mu \mathrm{g}$ of the proteins of $0.5 \mathrm{M}$ EDTA extract (E fraction), $4 \mathrm{M}$ guanidine $/ \mathrm{HCl}$ extraction ( $\mathrm{G}$ fraction) and cyanogen bromide digest ( $\mathrm{CB}$ peptide) were applied. $\alpha 1 \mathrm{CB}$ peptides and $\alpha 2 \mathrm{CB}$ peptides are both derived from the $\alpha 1$ chain and $\alpha 2$ chain of collagen. (B) E fraction was stained with Stains All. Polyacrylamide gels of $12.5 \%$ were used for all experiments. Arrows indicate the molecular weight of the main bands.

\section{Ion exchange chromatographic analysis}

The EDTA extracts of experimental and control samples were subjected to RESOURCE-Q chromatography (Fig. 4). Ten $\mu$ g of each protein dissolved in distilled water were applied to the column. Purified phosphophoryns were eluted as a peak at 25 minutes in this system. The peak of dentin phosphophoryns was observed in the chromatographic profiles of both the control and experimental fractions. The amount of phosphophoryns per $\mathrm{E}$ fraction was elevated in the experimental group (Table 1). Phosphophoryns could not be detected in the $\mathrm{CNBr}$ digest of the insoluble matrix of both the control and the experimental materials. These results indicate that all the phosphophoryns were extracted into the $\mathrm{E}$ fraction.

\section{Discussion}

In the present study, mineralization of dentin was obviously interfered with by HEBP administration, in the soft $\mathrm{X}$-ray photographs. This phenomenon has been histologically demonstrated by several investigators using single, daily and continual injection ${ }^{15,16,28)}$.

Daily and continual injection demonstrated a series of alternating rows of mineralized and non-mineralized dentin islands in the newly formed portion of the crown-analogue of rat incisors. The average distance between the adjacent mineralized dentin islands was approximately $400-500 \mu \mathrm{m}^{28}$. In our examination, seven weeks of administration of the drug was thought to interfere with mineralization in the majority of the dentin.

It has been reported that bisphosphonates interfere 


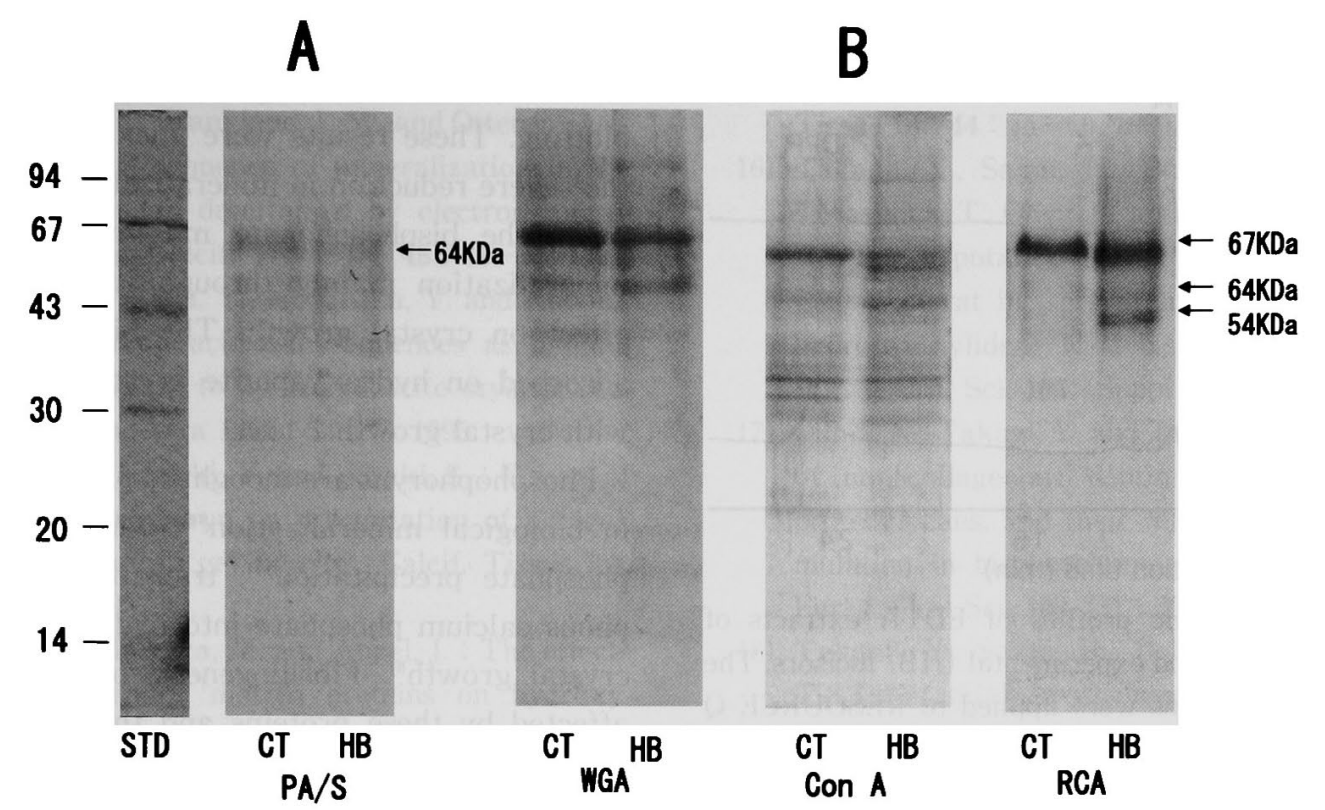

Fig. $3 \mathrm{PA} / \mathrm{S}$ staining and lectin blotting analysis of $\mathrm{E}$ fraction of control (CT) and experimental (HB) incisors. After electrophoresis, the proteins were transferred to nitrocellulose membranes by a semi-dry electroblotting apparatus. (A) The membranes were incubated with $1 \%$ periodic acid in $3 \%$ acetic acid and put into Schiff's reagent solution. (B) The membranes after transfer were washed with Tris buffer saline (TBS) and blocked with $2 \%$ bovine serum albumin (BSA). Then they were incubated in $1 \mu \mathrm{g}$ of lectins. The lectins used were wheat germ agglutinin (WGA), concanavalin A (Con A) and Ricinus communis agglutinin (RCA) conjugated with peroxidase. Arrows indicate the molecular weight of the main bands.

with the mineralization of dentin in two independent ways in single injections. Two hypomineralized lesions were observed histologically in the dentin of rats injected with a bisphosphonate ${ }^{15}$. One lesion was characterized by a reduction in mineral crystals and the other was characterized by a reduction in collagen fibrils. The former lesion may have been caused by a physicochemical effect of bisphosphonate on crystal growth. The latter lesion indicates that bisphosphonate impairs synthesis and/or deposition of matrix proteins.

Van den Bos and Beertsen ${ }^{24)}$ reported that bisphosphonate reduces synthesis of phosphophoryns and collagen. In their experiment, bisphosphonate was administered for 8-9 days and de novo synthesis of proteins was analyzed. In the short-term experiment, protein synthesis of odontoblasts was shown to be impaired by bisphosphonate ${ }^{24)}$, and they exhibated loss of height and polarity of shape ${ }^{29)}$.

On the other hand, it is possible for bisphosphonates to interfere with calcium ion transfer into a mineralization site. There are two channels through which calcium ions are supplied to a mineralization site. One is through the odontoblasts and another is through the intercellular space ${ }^{30-32)}$. Takano et al ${ }^{16)}$ reported that the inhibitory effect of systemically administer HEBP on dentin mineralization takes place primarily in the extracellular environment. They also stated that HEBP may have no appreciable influence on calcium transport across a biological membrane ${ }^{16)}$.

It seems unclear how bisphosphonates affect odontoblasts. Two ways have been speculated through which the bisphosphonates could have reduced matrix synthesis and calcium ion transfer as described above. In the current studies, it is possible that the drug promoted cell activity ${ }^{33,34}$. . HEBP has been reported to 


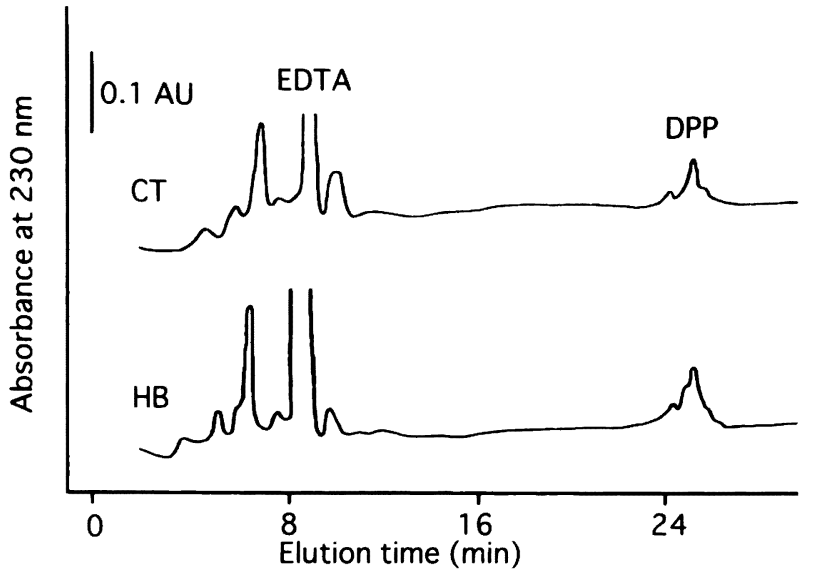

Fig. 4 Chromatographic profiles of EDTA extracts of control (CT) and experimental (HB) incisors. The $20 \mu \mathrm{g}$ of proteins were applied to RESOURCE-Q ion exchange column. It was eluted with a $0-0.7$ $\mathrm{mol} / \mathrm{l}$ linear gradient of $\mathrm{NaCl}$ in a Tris/ $\mathrm{HCl}$ pH 8.2 buffer. The elution was monitored with absorbance at $230 \mathrm{~nm}$. Peaks of EDTA and phosphophoryns (DPP) are indicated. The heights of the major peaks were measured for quantification of phosphophoryns.

elevate dentin phosphoprotein synthesis by rat odontoblasts in vitro ${ }^{35}$. Takano et al. ${ }^{16)}$ observed phosphophoryn-calcium deposits in non-mineralized circumpulpal dentin affected by HEBP. These reports support our results that phosphophoryn was elevated in non-mineralized dentin. Seven weeks of administration of HEBP in the concentration used here may at least not injure odontoblasts.

In the present examination, differences in matrix composition between the dentin affected by HEBP and the control were not observed. Furthermore, phosphophoryns, major matrix proteins which affect mineralization, were elevated by the drug considerably. These facts imply that the inhibition of mineralization is not mainly explained by the change of the matrix proteins, but by the inhibition of the calcium phosphate precipitation.

We examined the effect on matrix proteins in more detail with a longer period of administration. In contrast to the results of the previous investigators, amounts of non-collagenous proteins, especially those of phosphophoryns, were increased in rats injected with bisphosphonate. Regarding other non-col- lagenous proteins, no marked change in their composition was observed using electrophoresis and lectin blotting. These results were unexpected considering the severe reduction in mineralization. In this experiment, the bisphosphonate may have inhibited the mineralization mainly through its physicochemical effect on crystal growth. The bisphosphonate was adsorbed on hydroxyapatite crystals and interfered with crystal growth.

Phosphophoryns are thought to play important roles in biological mineralization ${ }^{36}$. They affect calcium phosphate precipitation ${ }^{37)}$, transformation of amorphous calcium phosphate into hydroxyapatite ${ }^{38)}$, and crystal growth ${ }^{8}$. Fibrillogenesis of collagen is also affected by these proteins and they are closely associated with sites of mineralization ${ }^{39}$.

Protein synthesis may have been recovered during long-term administration in the present experiment. The increase in phosphophoryn content can be explained by either an increase in biosynthesis or a decrease in degradation. Degradation products of phosphophoryns were not decreased by the administration of bisphosphonate, because no change was observed in the band of degradation products in the HEBP group compared with that in the control. Therefore, the latter possibility may not be plausible. Phosphophoryn biosynthesis may have been increased by the treatment. Further statistical study will be necessary in future experiments.

In the present experiment, the inhibitory effect of the bisphosphonate on mineralization may have overcome the nucleating effect of phosphophoryns.

\section{Acknowledgements}

This work was supported by a Grant-in-Aid from the Ministry of Education, Science, Sports and Culture of Japan (No. 06671845).

\section{References}

1) Linde, A., Bhown, M. and Butler, W. T. : Noncollagenous proteins of dentin. J. Biol. Chem. 255 (12) : 5931-5942, 1980.

2) Butler, W. T. and Ritchie, H. : The nature and func- 
tional significance of dentin extracellular matrix proteins. Int. J. Dev. Biol. 39 : 169-179, 1995.

3) Arsenault, A. L., Frankland, L. W. and Ottensmeyer, F.P. : Vectorial sequence of mineralization in the turkey leg tendon determined by electron microscopic imaging. Calcif. Tissue Int. 48: 46-55, 1991.

4) Fujisawa, R., Wada, Y., Nodasaka, Y. and Kuboki, $\mathrm{Y}$ : Acidic amino acid-rich sequences as binding site of osteonectin to hydroxyapatite crystal. Biophys. Biochim. Acta 1292: 53-60, 1995.

5) Fujisawa, R., Kuboki, Y. and Sasaki, S. : Effects of dentin phosphophoryn on precipitation of octacalcium phosphate in gel in vitro. Calcif. Tissue Int. 41: 44-47, 1987.

6) Boskey, A., Maresca, M. and Appel, J. : The effects of noncollagenous matrix proteins on hydroxyapatite formation and proliferation in a collage gel system. Conn. Tiss. Res. 21 : 171-178, 1989.

7) Linde, A., Lussi, A. and Crenshaw, M. A. : Mineral induction by immobilized polyanionic proteins. Calcif. Tissue Int. 44:286-295, 1989.

8) Fujisawa, R. and Kuboki, Y. : Preferential adsorption of dentin and bone acidic proteins on the (100) face of hydroxyapatite crystals. Biophys. Biochim. Acta 1075 : 56-60, 1991.

9) Furedi-Milhofer, H., Moradian-Oldak, J., Weiner, S., Veis, A., Mintz, K. P. and Addadi, L. : Interaction of matrix proteins from mineralized tissues with octacalcium phosphate. Conn. Tiss. Res. 31 (1) : 1-10, 1994.

10) Fujisawa, R. and Kuboki, Y.: Conformation of dentin phosphophoryn adsorbed on hydroxyapatite crystals. Eur. J. Oral Sci. 106 Suppl $1: 249-253$, 1998.

11) Wada, Y., Fujisawa, R. and Kuboki, Y. : A simple method to survey proteins which affect in vitro mineralization. Jpn. J. Oral Biol. 35 : 439-442, 1993.

12) Wada, Y., Fujisawa, R., Nodasaka, Y. and Kuboki, Y. : Electrophoretic gels of dentin matrix proteins as diffusion media for in vitro mineralization. J. Dent. Res. 75 (6) : 1381-1387, 1996.

13) Fleisch, H. and Felix, R. : Diphosphonates. Calcif. Tissue Int. $27: 91-94,1979$.

14) Shinoda, H., Adamek, G., Felix, R., Fleisch, H., Schenk, R. and Hagan, P. : Structure-activity relationships of various bisphosphonate. Calcif. Tissue Int. 35: 87-99, 1983.

15) Ogawa, Y., Adachi, Y., Hong, S. and Yagi, T. : 1Hydroxyethylidene-1, 1-bisphosphate (HEBP) simultaneously induces two distinct types of hypomineralization in the rat incisor dentin. Calcif. Tissue Int. 44:46-60, 1989.

16) Takano, Y., Sakai, H., Baba, O., Sakamoto, Y., Terashima, T., Ohya, K. and Kurosaki, N. : Demonstration of putative Ca-binding domains in dentin matrix of rat incisors after daily injections of 1 hydroxyethylidene-1, 1-bisphosphonate (HEBP). Eur. J. Oral Sci. 106 (Suppl 1) : 274-281, 1998.

17) Ohma, N., Takagi, Y. and Takano, Y. : Distribution of non-collagenous dentin matrix proteins and proteoglycans, and their relation to calcium accumulation in bisphosphonate-affected rat incisors. Eur. J. Oral Sci. 108 (3) : 222-232, 2000.

18) Takano, Y., Sakai, H., Baba, O. and Terashima, T. : Differential involvement of matrix vesicles during the initial and appositional mineralization processes in bone, dentin, and cementum. Bone 26 (4) : 333-339, 2000.

19) Watanabe, E. and Takano, Y.: Ca-binding domains in the odontoblast layer of rat molars and incisors under normal and pathological conditions. Arch. Histol. Cytol. 65 (4) : 337-346, 2002.

20) Fleisch, H. and Russel, R. G. G. : A review of the physiological and pharmacological effects of pyrophosphate and diphosphonates on bone and teeth. J. Dent. Res. 51:324-332, 1972.

21) Guenther, H. L., Guenther, H. E. and Fleisch, H. : The effects of 1-hydroxyethane-1, 1-diphosphonate and dichloromethanediphosphonate on collagen synthesis by rabbit articular chondrocytes and rat bone cells. Biochem. J. 196 : 293-301, 1981.

22) Guenther, H. L., Guenther, H. E. and Freisch, H. : The influence of 1-hydroxyethane-1, 1-diphosphonate and dichloromethanediphosphonate on lysine hydroxylation and cross-link formation in rat bone, cartilage and skin collagen. Biochem. J. 196 : 303-310, 1981.

23) Francis, M. D. and Martodam, P. R. : Chemical, biochemical and medicinal properties of the diphosphonates. In: The role of phosphonates in living systems. (edited by Hilderbrand, R. L.), pp.55-96, CRC Press Inc., Boca Raton, 1983.

24) Van den Bos, T. and Beertsen, W. : Effects of 1hydroxyethylidene-1, 1-bisphosphonate (HEBP) on the synthesis of dentin matrix proteins in the mouse. Col. Rel. Res. 7 : 135-147, 1987.

25) Domenicucci, C., Goldberg, H. A., Hofmann, T., Isenman, D., Wasi, S. and Sodek, J. : Characteriza- 
tion of porcine osteonectin extracted from foetl calvariae. Biochem. J. 253 : 139-151, 1988.

26) Otsuka, K., Ling Yao, K., Wasi, S., Tung, P. S., Aubin, J. E., Sodek, J. and Termine, J. D. : Biosynthesis of osteonectin by fetal porcine calvarial cells in vitro. J. Biol. Chem. 259 (15) : 9805-9812, 1984.

27) Zacharius, R.M., Zell, T.E., Morrison, J.H. and Woodlock, J. J. : Glycoprotein staining following electrophoresis on acrylamide gels. Anal. Biochem. 30 : 148-152, 1969.

28) Sakai, H., Takano, Y., Ohya, K. and Kurosaki, N. : Intermittent inhibition of dentin mineralization of rat incisors under continual infusion of 1-hydroxyethylidene-1, 1-bisphosphonate (HEBP) using a subcutaneous mini osmotic pump. Arch. Histol. Cytol. 62 (2) : 171-179, 1999.

29) Beertsen, W., Niehof, A. and Everts, V. : Effects of 1-hydroxyethylidene-1, 1-bisphosphonate (HEBP) on the formation of dentin and periodontal attachment apparatus in the mouse. Am. J. Anat. 174 : 83-103, 1985.

30) Nagai, N. and Frank, R. M. : Electron microscopic autoradiography of ${ }^{45} \mathrm{Ca}$ during dentinogenesis. Cell. Tiss. Res. 155: 513-523, 1974.

31) Reith, E. J.: The binding of calcium within the Golgi saccules of rat odontoblast. Am. J. Anat. 147: 267-272, 1976.

32) Ozawa, H., Yamada, M. and Yamamoto, T.: Ultrastructual observations on the location of lead and calcium in the mineralizing dentine of rat incisors. In: "Matrix Vesicles". (edited by Aszenzi A., et al.). pp.179-187, Wichtig Editore, Milano, 1981.

33) Tenenbaum, H.C., Torontali, M. and Sukhu, B. : Effects of bisphosphonates and inorganic pyrophosphate on osteogenesis in vitro. Bone $13: 249-255$, 1992.

34) Giuliani, N., Pedrazzoni, M., Negri, G., Passeri, G., Impicciatore, M. and Girasole, G. : Bisphosphonates stimulate formation of osteoblast precursors and mineralized nodules in murine and human bone marrow cultures in vitro and promote early osteoblastgenesis in young and aged mice in vivo. Bone 22 : 455-461, 1998.

35) Fujisawa, R., Wada, Y., Mizuno, M. and Kuboki, Y. : Upreguration of dentin matrix protein synthesis by in vitro administration of bisphosphonate. Jpn. J. Oral Biol. 41 : 443, 1999.

36) Dimuzio, M. and Veis, A. : Phosphophoryns-major noncollagenous proteins of rat incisor. Calc. Tiss. Res. 225 : 169-178, 1978.

37) Termine, J. D., Eanes, E. D. and Conn, K. M. : Phosphoprotein modulation of apatite crystallization. Calcif. Tissue Int. 31 : 247-251, 1980.

38) Doi, Y., Horiguchi, T., Kim, S., Moriwaki, Y., Wakamatsu, N., Adachi, M., Shigeta, H., Sasaki, S. and Shimokawa, H. : Immobilized DPP and other proteins modify OCP formation. Calcif. Tissue Int. 52: 139-145, 1993.

39) Traub, W., Jodaikin, A., Arad, T., Veis, A. and Sabsay, B. : Dentin phosphophoryn binding to collagen fibrils. Matrix 12:197-201, 1992. 